\title{
Process Integration of Material Flows of Copper Chlorides in the Thermochemical Cu- Cl Cycle
}

\author{
Kevin Pope ${ }^{1}$, Zhaolin Wang ${ }^{2}$ and Greg F. Naterer ${ }^{3}$ \\ ${ }^{1,3}$ Memorial University of Newfoundland \\ ${ }^{2}$ University of Ontario Institute of Technology \\ ${ }^{1}$ kpope@mun.ca, ${ }^{2}$ forest.wang@uoit.ca, ${ }^{3}$ gnaterer@mun.ca
}

\begin{abstract}
The copper-chlorine $(\mathrm{Cu}-\mathrm{Cl})$ thermochemical hydrogen production cycle consists of three chemical reactions, i.e., electrolyisis of copper (I) chloride $(\mathrm{CuCl})$ and hydrogen chloride $(\mathrm{HCl})$, hydrolysis of copper (II) chloride $\left(\mathrm{CuCl}_{2}\right)$, and thermolysis of copper oxychloride $\left(\mathrm{Cu}_{2} \mathrm{OCl}_{2}\right)$. The outlet stream of the electrolysis includes aqueous $\mathrm{CuCl}_{2}, \mathrm{CuCl}$, and $\mathrm{HCl}$. The $\mathrm{CuCl}_{2}$ product of the electrolysis is the reactant of downstream hydrolysis. In this paper, three integration pathways for the copper chloride flows between electrolysis and hydrolysis reactors are investigated in terms of energy saving and reduction of auxiliary operations for the processing of the flows. The integration pathways include solid precipitation of $\mathrm{CuCl}_{2}$ using a crystallization process, water vaporization in the hydrolysis reactor by introducing the electrolyzer outlet stream directly to the reactor, and vaporization in an intermediate spray dryer.
\end{abstract}

Keywords: hydrogen production, $\mathrm{Cu}-\mathrm{Cl}$ cycle, energy efficiency, process integration

\section{INTRODUCTION}

As energy demand grows, the reliance on fossil fuels to fulfill energy requirements will cause substantial environmental consequences. To meet the increasing demand while reducing GHG emissions, renewable energy systems and fuels have been sought as an alternative to combusting fossil fuels. Hydrogen has been viewed as a promising fuel with a combustion product of clean water. It can fuel specially designed internal combustion engines or fuel cells for a variety of energy needs [1].

\footnotetext{
${ }^{2}$ Corresponding author

Zhaolin Wang, Clean Energy Research Laboratory, University of Ontario Institute of Technology, 2000 Simcoe St N, Oshawa, Ontario, L1H 7K4, Canada zhaolin.wang@uoit.ca 1-905-721-8668 ext 3478
} 
However, due to its high reactivity, hydrogen gas does not naturally exist and is typically part of larger molecules, such as water $\left(\mathrm{H}_{2} \mathrm{O}\right)$ or methane $\left(\mathrm{CH}_{4}\right)$. Currently, hydrogen is primarily derived from fossil fuels: $48 \%$ from steam methane reforming (SMR), 30\% from refinery / chemical off-gases, and $18 \%$ from coal gasification (water electrolysis produces less than $4 \%$ of the total hydrogen production) [2, 3]. The environmental benefits of using hydrogen in a vehicle could be significant, but is dependent on the source of the hydrogen. Producing hydrogen from fossil fuels consumes finite natural resources and releases large quantities of GHG emissions which is unsustainable. Alternative methods for hydrogen production that avoid or limit using fossil fuels and reduce GHG emissions are needed.

One method for hydrogen production uses electrolysis to split water molecules into constituent hydrogen and oxygen molecules, and the electricity for the electrolysis could be generated from nuclear or solar thermal energy. However, there is a significant energy loss when the thermal energy is converted to electricity. If the thermal energy can be used to split water into hydrogen and oxygen thermally, the production efficiency can be substantially increased. However, direct splitting of 35\% water vapour requires a temperature of at least $3,000^{\circ} \mathrm{C}$ [4], which is a very challenging temperature for industrial processes. To overcome this temperature issue, many investigators are developing indirect thermal decomposition cycles, which are termed as thermochemcial cycles. In a thermochemical cycle, water molecules first associate with auxiliary chemicals to form intermediate compounds, and then these compounds release hydrogen and oxygen. In the overall reaction, water is the only reactant entering the cycle that consists of several auxiliary and intermediate processes, and hydrogen and oxygen are the only products out of the cycle.

Approximately two hundred thermochemical cycles have been reported [5 - 7], among which the copper-chlorine ( $\mathrm{Cu}-\mathrm{Cl}$ ) cycle is a promising method of hydrogen production. The $\mathrm{Cu}-\mathrm{Cl}$ cycle is a hybrid cycle consisting of three chemical reactions, i.e., electrolysis of aqueous $\mathrm{CuCl}$ and $\mathrm{HCl}$ for hydrogen and $\mathrm{CuCl}_{2}$ production, hydrolysis of $\mathrm{CuCl}_{2}$ with steam for the production of $\mathrm{Cu}_{2} \mathrm{OCl}_{2}$, which releases oxygen in its downstream thermolysis reaction. The three reactions are listed as follows:

$$
\begin{aligned}
& 2 \mathrm{CuCl}(\mathrm{aq})+2 \mathrm{HCl}(\mathrm{aq})=\mathrm{H}_{2}(\mathrm{~g})+2 \mathrm{CuCl}_{2}(\mathrm{aq}), 70-100^{\circ} \mathrm{C}(\text { Electrolysis of } \mathrm{CuCl} \text { and } \mathrm{HCl}) \\
& 2 \mathrm{CuCl}_{2}(\mathrm{~s})+\mathrm{H}_{2} \mathrm{O}(\mathrm{g})=\mathrm{Cu}_{2} \mathrm{OCl}_{2}(\mathrm{~s})+2 \mathrm{HCl}(\mathrm{g}), 360-390^{\circ} \mathrm{C}\left(\text { Hydrolysis of } \mathrm{CuCl}_{2}\right)
\end{aligned}
$$


$\mathrm{Cu}_{2} \mathrm{OCl}_{2}(\mathrm{~s})=2 \mathrm{CuCl}(\mathrm{l})+1 / 2 \mathrm{O}_{2}(\mathrm{~g}), 360-390^{\circ} \mathrm{C}\left(\right.$ Thermolysis of $\left.\mathrm{Cu}_{2} \mathrm{OCl}_{2}\right)$

where aq, g, l, and s in brackets represent aqueous, gaseous, liquid, and solid, respectively. The liquid subscript indicates a molten state of the salt rather than aqueous, although aqueous solution exists in liquid form. The $\mathrm{Cu}-\mathrm{Cl}$ cycle can form a closed loop with the $\mathrm{CuCl}$ - $\mathrm{HCl}$ electrolyzer to produce hydrogen without external emissions to the atmosphere. Advantage of this cycle is as follows. Temperature of the heat for the cycle is significantly lower than that for many other cycles. Also, the $\mathrm{Cu}-\mathrm{Cl}$ cycle has considerably lower electrical power requirement, compared to typical water electrolysis, by using a $\mathrm{CuCl}$ - $\mathrm{HCl}$ electrolyzer.

The $\mathrm{Cu}-\mathrm{Cl}$ cycle for hydrogen production [8], which consists of 3 chemical reactions and auxiliary physical processes. A closed cycle can be formed in a variety of ways and there are different variations of the $\mathrm{Cu}-\mathrm{Cl}$ cycle [9], but the linkage of the copper (II) chloride $\left(\mathrm{CuCl}_{2}\right)$ in the outlet stream from the $\mathrm{CuCl}$ - $\mathrm{HCl}$ electrolyzer (reaction 1) with the reactant flow of the $\mathrm{CuCl}_{2}$ hydrolysis (reaction 2) is always required in different variations, and there are different linkage options which may influence the energy requirement and number of auxiliary unit operations.

In this paper, integrating the electrolyzer and hydrolysis reactors in the $\mathrm{Cu}-\mathrm{Cl}$ cycle is investigated in terms of the number of auxiliary operations, energy requirement, and mass flows to evaluate the feasibility of three integration pathways, including (i) vaporizing the electrolyzer's outlet stream in the hydrolysis reactor, (ii) vaporizing excess $\mathrm{H}_{2} \mathrm{O}$ in a spray dryer before the hydrolysis reactor, and (iii) crystallizing $\mathrm{CuCl}_{2}$ by using solubility changes at different temperatures to remove excess water before the hydrolysis reactor. The study of different pathways can provide valuable information for a compact and energy efficient method to integrate the processes of the $\mathrm{Cu}-\mathrm{Cl}$ cycle.

\section{LINKAGE COMPLEXITY AND NUMBER OF MAJOR AUXILIARY OPERATIONS}

To directly link the electrolysis (reaction 1) and hydrolysis (reaction 2) reactors, the $\mathrm{H}_{2} \mathrm{O}$ content of the aqueous solution can be directly used as the reactant in the hydrolysis reaction, as illustrated in Figure 1. However, according to past studies [10, 11], the water content in the solution is several times higher than required by the downstream hydrolysis reaction. Numerous interconnected variables affect the water content quantities in the electrolyzer outlet and hydrolysis inlet and optimal 
quantities are not fully determined in previous research. In this paper, ranges of water content (based on previous research) are investigated to help identify optimal operating conditions and integration techniques. An additional vaporization requirement is introduced into the hydrolysis reactor and additional steam- $\mathrm{HCl}$ separation processes are required downstream of the hydrolysis reactor. Detailed studies on the conversion extent of the solid hydrolysis reactant predict an optimal steam conversion of 4 to $15 \mathrm{~mol}$ of $\mathrm{H}_{2} \mathrm{O}$ per mol of $\mathrm{HCl}$ produced [12]. To reduce the vaporization load of the hydrolysis reaction and improve the thermal efficiency of the $\mathrm{Cu}-\mathrm{Cl}$ cycle, the water in the aqueous solution must be significantly reduced in the $\mathrm{CuCl}_{2}$ solution before entering the hydrolysis reactor. This introduces some engineering challenges into the process integration of reactions (1) and (2), including the selection of a technology to obtain $\mathrm{CuCl}_{2}$ solid from its aqueous solution and a method to remove the water content at a low cost. This optimum $\mathrm{H}_{2} \mathrm{O}$ amount for the hydrolysis reaction requires much heat for $\mathrm{H} 2 \mathrm{O}$ vaporization. Optimization of $\mathrm{H}_{2} \mathrm{O}$ amount is required considering these factors.

In the $\mathrm{CuCl}$ electrolyzer of reaction (1), recent estimations from experimental results suggest a practicable conversion extent (with high efficiency) of 50 - 65\% [13, 14], which indicates that unreacted $\mathrm{CuCl}$ will be in the outlet stream of the electrolyzer. This complicates reactor integration, requiring $\mathrm{CuCl}_{2}$ and $\mathrm{CuCl}$ separation. Furthermore, altered conversions will change the outlet stream compositions and complicate the concentrating process.

A spray dryer which extracts solid $\mathrm{CuCl}_{2}$ from aqueous solution from electrolysis is the second option. A spray dryer is a common method to produce powder from slurry. Figure 2 illustrates the schematic of this linkage pathway. To operate the spray drying process, a drying gas is needed. Air is easy to obtain and can be operated at a lower cost than other pure gases. However, the oxygen in air will oxidize $\mathrm{CuCl}$ entrained in the $\mathrm{CuCl}_{2}$ aqueous solution, therefore, an inert gas must be used to vaporize the water in the $\mathrm{CuCl}_{2}$ aqueous solution. After drying, the gaseous $\mathrm{HCl}$ and $\mathrm{H}_{2} \mathrm{O}$ must be recovered, which requires a recovery unit to separate the drying gas from gaseous $\mathrm{HCl}$ and $\mathrm{H}_{2} \mathrm{O}$. For full recovery, the $\mathrm{H}_{2} \mathrm{O}$ must be fully condensed to absorb $\mathrm{HCl}$ to form aqueous $\mathrm{HCl}$, which requires a condenser or vapour liquefaction system. To completely remove toxic gaseous $\mathrm{HCl}$ from the drying gas is energy intensive, and the inert drying gas is more expensive than air, requiring the drying gas to be 
recycled. Numerous energy intensive operations are needed to use spray drying as the linkage pathway for the copper chloride flows.

Figure 3 illustrates a third integration option that crystallizes the electrolyzer's outlet stream before the hydrolysis reactor. The outlet stream flows into a heat exchanger, i.e., a cooler, and then a portion of solid crystalline $\mathrm{CuCl}_{2}$ and $\mathrm{CuCl}$ precipitates out of the aqueous solution due to the solubility change at different temperatures. The residual clear solution of the crystallizer is pumped back to the electrolyzer and the precipitated solids $\left(\mathrm{CuCl}_{2}\right.$ and $\left.\mathrm{CuCl}\right)$ are conveyed into the hydrolysis reactor. Compared with spray drying, crystallization requires less auxiliary operations, as well as preventing $\mathrm{HCl}$ from entering the hydrolysis reactor, which will improve the reactant extent, as presented in Eq. (2). Reducing the excess steam in the hydrolysis reactor simplifies integrating $\mathrm{HCl}$ in the hydrolyzer outlet stream with $\mathrm{HCl}$ in electrolyzer influent, by preventing an additional concentration process.

A compact cycle with fewer processes is typically preferred for operational simplicity and cost. The integration complexity is reflected by the number of major auxiliary processes needed to conduct the copper chloride flows to the desired chemical reactors. In addition to the number of major auxiliary processes that are needed to conduct the flows to the desired chemical reactors, energy requirement is a more significant consideration. It is preferred that the energy saving pathway is selected for the linkage. The following sections calculate the energy requirement for the three pathways.

\section{FORMULATION OF ENERGY REQUIREMENTS OF CU-CL CYCLE INTEGRATION}

In this section, the thermodynamic formulation for integrating the electrolyzer and hydrolysis reactor is presented. In the $\mathrm{Cu}-\mathrm{Cl}$ cycle, achieving complete conversion is difficult and is a challenge to process integration by significantly reducing the thermodynamic efficiency of the cycle as chemical conversion effectiveness reduces as the reactants are consumed [15]. The heat input is calculated in the following way. The minimum thermal energy input to integrate the electrolyzer and hydrolysis reactor can be represented by

$$
\Delta H_{T}=f\left(\Delta H_{C p, \text { water }}, \Delta H_{C p, \text { steam }}, H_{\text {latent } \mathrm{H}_{2} \mathrm{O}}, \Delta H_{\mathrm{Cp}, \mathrm{CuCl}_{2}}, \Delta H_{\mathrm{Cp}, \mathrm{CuCl}}, \Delta H_{\mathrm{Cp}, \mathrm{HCl}}, \Delta H_{r, \mathrm{CuCl}_{2} \bullet \mathrm{H}_{2} \mathrm{O}}\right)
$$


where $H_{C p \text {,water }}, H_{C p, \text { steam }}, H_{\text {latent }, \mathrm{H}_{2} \mathrm{O}}, H_{C p, \mathrm{CuCl}_{2}}, H_{\mathrm{Cp}, \mathrm{CuCl}}, \Delta H_{\mathrm{Cp}, \mathrm{HCl}}$ and $\Delta H_{r, \mathrm{CuCl}_{2} \bullet \mathrm{H}_{2} \mathrm{O}}$ represent the energy requirement to elevate the water temperature, to elevate the steam temperature, to convert water to steam, to elevate the $\mathrm{CuCl}_{2}$ temperature, to elevate the $\mathrm{CuCl}$ temperature, to elevate the $\mathrm{HCl}$ temperature and to hydrated $\mathrm{CuCl}_{2}$.

The thermal input for temperature elevation can be represented by

$$
Q=n C_{p} \Delta T
$$

where $n, C_{p}$, and $\Delta T$ represent the mole number, the heat capacity and the temperature change. $\mathrm{H}_{2} \mathrm{O}$ phase change can be represented by

$$
H_{\text {latent }}=n \beta
$$

where $\beta$ represents the enthalpy of vaporization coefficient. The crystallization process is represented by $\mathrm{CuCl}_{2}(\mathrm{aq})+\left(\mathrm{n}_{\mathrm{w}}+\mathrm{m}_{\mathrm{w}}\right) \mathrm{H}_{2} \mathrm{O}(\mathrm{l})=\mathrm{CuCl}_{2} \bullet \mathrm{n}_{\mathrm{w}} \mathrm{H}_{2} \mathrm{O}(\mathrm{s})+\mathrm{m}_{\mathrm{w}} \mathrm{H}_{2} \mathrm{O}(\mathrm{l})$, below $60^{\circ} \mathrm{C}$

where $\mathrm{n}_{\mathrm{w}}+\mathrm{m}_{\mathrm{w}}$, represents the total number water molecules, per mole of $\mathrm{CuCl}_{2}$, in the aqueous solution. On the right-hand-side of Eq. (7), $\mathrm{n}_{\mathrm{w}}$ represents the number of water molecules that are in a crystallized form with $\mathrm{CuCl}_{2}$ to form copper (II) chloride hydrate, the magnitude of $\mathrm{n}_{\mathrm{w}}$ can be from 0 - 4 , depending on the temperature [16 - 20] and it can be a non-integer if the crystallization final state does not reach equilibrium [21]. The crystallization effectiveness is calculated by

$$
\zeta_{s, i^{\circ} \mathrm{C}}=\frac{n_{s, 80^{\circ} \mathrm{C}}-n_{s, i^{\circ} \mathrm{C}}}{n_{s, 80^{\circ} \mathrm{C}}}
$$

where $\mathrm{n}_{\mathrm{s}}$ represents the molar quantity of $\mathrm{CuCl}_{2}$ in solid phase. The subscript $i^{\circ} \mathrm{C}$ represents the output temperature of the crystallizer. The steam requirement $(\xi)$ in the hydrolysis reactor can be defined by

$$
\xi=\frac{n_{\mathrm{H}_{2} \mathrm{O}}}{n_{\mathrm{CuCl}_{2}}}
$$

where the stoichiometric minimum value for $\xi$ is 0.5 . Material flows are determined from previous research and experimental data. Recent experiments [22] and thermodynamic analysis [23, 24] suggest an optimal temperature of the hydrolysis reactor to be approximately $375^{\circ} \mathrm{C}$. In this paper, the calculations are conducted in Microsoft Excel, and all pressures are maintained at ambient. 


\section{RESUlTS AND DISCUSSION}

\subsection{Effects of electrolysis extent and outlet stream composition on the energy requirements.}

In this section the results of the thermodynamic analysis of integrating the electrolysis and hydrolysis reactors is presented. In Table 1 , the crystallization properties of a $\mathrm{CuCl}_{2}-\mathrm{CuCl}-\mathrm{HCl}$ solution are presented for 1 litre of solution between $20^{\circ} \mathrm{C}$ and $80^{\circ} \mathrm{C}$ on the basis of the assumption is that crystallization operates on the solubility curve, i.e., the operation line obeys the solubility curve, which will be discussed later in this paper.

Figure 4 [25] illustrates the solubility curve and operation line of the crystallization in a ternary system of $\mathrm{CuCl}_{2}, \mathrm{HCl}$, and water, where the $\mathrm{HCl}$ concentration is $2 \mathrm{M}$. Crystallization experiments were performed at the Clean Energy Research Laboratory (CERL) of the University of Ontario Institute of Technology (UOIT) to examine the repetition assumption. The solubility data was collected from previous studies [26, 27]. The solubility data at $80^{\circ} \mathrm{C}$ was not found in published literature. However, the starting temperature of crystallization was performed from $80^{\circ} \mathrm{C}$ to include the temperature of the electrolyzer's outlet stream.

For each temperature, the solution at the inlet of the crystallizer was selected based on the ratio of $\mathrm{CuCl}_{2}-\mathrm{CuCl}-\mathrm{HCl}$ in the solution to best match the concentration of the electrolyzer outlet stream (between $50 \%$ and $65 \%$ conversion of $\mathrm{CuCl}$ to $\mathrm{CuCl}_{2}$ ).

In Figure 5 the crystallization effectiveness ( $\xi$ ) is calculated by Eq. (8) and the amount of solids are determined by the product of crystallization effectiveness and molar input. As presented in Figure 5 , the crystallization of $\mathrm{CuCl}$ is negligible between $80^{\circ} \mathrm{C}$ and $60^{\circ} \mathrm{C}$ temperature of $18 \%$ of $\mathrm{CuCl}_{2}$ crystallization. However, as presented in Table 1 , the $\mathrm{HCl}$ concentration is increased from $6.09 \mathrm{M}$ to $8.55 \mathrm{M}$ from $80^{\circ} \mathrm{C}$ to $60^{\circ} \mathrm{C}$, which will contribute to the relative quantities of $\mathrm{CuCl}$ and $\mathrm{CuCl}_{2}$ solids. Future experiments will determine the relative impacts of $\mathrm{HCl}$ on the solubility of $\mathrm{CuCl}$ and $\mathrm{CuCl}_{2}$ for limiting the crystallization of $\mathrm{CuCl}$. Adding $\mathrm{HCl}$ to the solution will improve crystallization properties.

When crystallization temperature is below $60^{\circ} \mathrm{C}, \xi \mathrm{CuCl}_{2}$ is higher. However, $\xi \mathrm{CuCl}$ also increases in the product. A crystallization solid output with a high concentration of $\mathrm{CuCl}_{2}$ will supply the hydrolysis reactor with a more pure reactant and enable higher hydrolysis efficiencies. However, $\mathrm{CuCl}$ will precipitate out of the solution (with $\mathrm{CuCl}_{2}$ ), which will reduce the purity of the hydrolysis 
reactant. Furthermore, higher conversion extents in the electrolyzer also increase the electricity consumption of the electrolytic process. To achieve high thermal efficiency in the $\mathrm{Cu}-\mathrm{Cl}$ cycle, an optimal balance between conversion extent as well as thermal and electrical energy input needs to be determined. Reducing the temperature to $20^{\circ} \mathrm{C}$ increases the solid fraction of $\mathrm{CuCl}_{2}$ to $42 \%$, with $31 \%$ $\mathrm{CuCl}$.

As presented in Figure 6, a significant portion of the energy input to the hydrolysis reactor is used to convert water to steam, particularly when the steam requirement ( $\xi$, steam to copper (II) chloride ratio) is high. If the outlet stream of the electrolyzer is introduced directly into the hydrolysis reactor, the steam to copper (II) chloride ratio will be in the range of 17 - 34 and require significant thermal input due to the high water vaporization load. This result highlights the importance of concentrating the electrolyzer outlet stream before it is directed to the hydrolysis reactor (i.e., the option shown in Figure 1, has a low thermal efficiency).

The hydrolysis energy requirement $(E)$ is linearly dependent on the steam requirement of the reactor, which can be represent by (at a reaction temperature of $375^{\circ} \mathrm{C}$ )

$E=61.587 \xi+14.784$

where $\xi$ represents the steam requirement. An excess steam requirement of $8 \mathrm{~mol} \mathrm{H}_{2} \mathrm{O}$ per mol of $\mathrm{CuCl}_{2}$ will require a minimum energy input of $507 \mathrm{~kJ} / \mathrm{mol}$. However, $17 \mathrm{~mol} \mathrm{H}_{2} \mathrm{O}$ and $34 \mathrm{~mol}_{2} \mathrm{O}$ per mol of $\mathrm{CuCl}_{2}$ will require a minimum energy input of $1062 \mathrm{~kJ} / \mathrm{mol}$ and $2109 \mathrm{~kJ} / \mathrm{mol}$, respectively. An excess steam requirement of $8 \mathrm{~mol} \mathrm{H}_{2} \mathrm{O}$ per mol of $\mathrm{CuCl}_{2}$ has been chosen because it is a balance between estimated values based on previous experimental research [12, 15].

Cooling the electrolyzer outlet stream, as needed for the crystallization process, will dissipate thermal energy from the cycle. The depleted thermal energy is low grade and cannot be easily recaptured for useful processes. In Figure 7, the thermal energy depleted in the crystallizer is presented for 3 conversion extents of the electrolyzer: $25 \%, 50 \%$, and $65 \%$. As presented in the right half of Table 1 , each conversion extent has a different concentration of outlet stream compounds. The lower concentration of $\mathrm{CuCl}_{2}$ (corresponding to lower conversion extents in the electrolyzer) produce a more dilute solution in terms of $\mathrm{CuCl}_{2}$, thus increasing the energy lost in the crystallizer, primarily due to 
thermal energy lost by cooling a greater quantity of $\mathrm{H}_{2} \mathrm{O}$. As indicated in Equation (7), a portion of the water exists in different forms before and after crystallization, so there is an enthalpy change accompanying the process. If the magnitude of $\mathrm{n}_{\mathrm{w}}$ is two (a likely result), the dehydration of $\mathrm{CuCl}_{2} \cdot 2 \mathrm{H}_{2} \mathrm{O}$ at $127^{\circ} \mathrm{C}$ has an enthalpy change of $117 \mathrm{~kJ} / \mathrm{mol}[28]$ :

$\mathrm{CuCl}_{2} \cdot 2 \mathrm{H}_{2} \mathrm{O}(\mathrm{s})=\mathrm{CuCl}_{2}(\mathrm{~s})+2 \mathrm{H}_{2} \mathrm{O}(\mathrm{g}), \Delta \mathrm{H}_{\mathrm{r}}=117 \mathrm{~kJ} / \mathrm{mol}$ at $127^{\circ} \mathrm{C}$

The positive value of $\Delta H$ in equation (11) indicates an endothermic dehydration process and its reverse process (i.e. hydration) is an exothermic, which leads to an additional thermal energy loss. Temperature has a negligible effect on enthalpy change in the range of $0-127^{\circ} \mathrm{C}$, suggesting the magnitude can be approximated by the hydration enthalpy change. Hydration starts from an initial state of liquid rather than gas and the vaporization enthalpy change of water is:

$2 \mathrm{H}_{2} \mathrm{O}(\mathrm{g})=2 \mathrm{H}_{2} \mathrm{O}(\mathrm{l}), \Delta \mathrm{H}_{\text {latent, } \mathrm{H}_{2} \mathrm{O}}=-78 \mathrm{~kJ} / \mathrm{mol}$ at $127^{\circ} \mathrm{C}$

The sum of equations (11) and (12) indicates an enthalpy of dehydration of $\mathrm{CuCl}_{2} \cdot 2 \mathrm{H}_{2} \mathrm{O}$ :

$\mathrm{CuCl}_{2} \cdot 2 \mathrm{H}_{2} \mathrm{O}(\mathrm{s})=\mathrm{CuCl}_{2}(\mathrm{~s})+2 \mathrm{H}_{2} \mathrm{O}(\mathrm{l}), \Delta H_{\text {dehydration }}=39 \mathrm{~kJ} / \mathrm{mol}$ at $127^{\circ} \mathrm{C}$

The reverse process of equation (13) provides a hydration enthalpy of copper (II) chloride hydrate of $\Delta \mathrm{H}_{r, \mathrm{CuCl}_{2} \bullet 2 \mathrm{H}_{2} \mathrm{O}}=-39 \mathrm{~kJ} / \mathrm{mol}$ :

$\mathrm{CuCl}_{2}(\mathrm{~s})+2 \mathrm{H}_{2} \mathrm{O}(\mathrm{l})=\mathrm{CuCl}_{2} \cdot 2 \mathrm{H}_{2} \mathrm{O}(\mathrm{s}), \Delta H_{r, \mathrm{CuCl}_{2} \cdot 2 \mathrm{H}_{2} \mathrm{O}}=-39 \mathrm{~kJ} / \mathrm{mol}$ at $127^{\circ} \mathrm{C}$

As illustrated in Figure 8, the quantity of $\mathrm{H}_{2} \mathrm{O}$ in the electrolyzer outlet stream rises significantly with reduced conversion extents. An input electrolyte solution of $2 \mathrm{M} \mathrm{CuCl}$ and $6 \mathrm{M} \mathrm{HCl}$, and a $50 \%$ conversion in an electrolyzer will produce an outlet stream of $1 \mathrm{~mol} \mathrm{CuCl}_{2}$ and $42.7 \mathrm{~mol} \mathrm{of} \mathrm{H}_{2} \mathrm{O}$. This is a significantly higher quantity of $\mathrm{H}_{2} \mathrm{O}$ than is likely required by the hydrolysis reactor $[15,29,30]$ and the excess water will require a significant quantity of thermal energy to heat to the required hydrolysis reaction temperature, increasing the minimum thermal energy requirement of the hydrolysis reactor to 2,940 $\mathrm{kJ}$ per mol of $\mathrm{CuCl}_{2}$, if the outlet stream is directly introduced to the hydrolysis reactor to provide the steam and $\mathrm{CuCl}_{2}$ reactants. 
Utilizing a crystallizer in the temperature range of $80^{\circ} \mathrm{C}$ to $60^{\circ} \mathrm{C}$, will lose $85 \mathrm{~kJ} / \mathrm{mol}$ into the crystallizer, to produce $0.18 \mathrm{~mol}$ of $\mathrm{CuCl}_{2}$ solids. To produce $1 \mathrm{~mol}$ of $\mathrm{CuCl}_{2}$ solids will lose $480 \mathrm{~kJ} / \mathrm{mol}$ of thermal energy contained in the solution (a comparable value in magnitude to the minimum energy requirement of the hydrolysis reactor with an excess steam requirement of $8\left(507 \mathrm{~kJ} / \mathrm{mol}\right.$ of $\left.\mathrm{CuCl}_{2}\right)$. The crystallizer offers appreciable advantages to the thermal efficiency of the $\mathrm{Cu}-\mathrm{Cl}$ cycle (the pathway illustrated in Fig. 1).

As presented in Table 2, a comparative energy requirement of the three integration pathways identifies crystallization as the preferred pathway to limit energy use in the cycle. The calculated minimum energy requirement of a hydrolysis reactor and crystallizer for several quantities of excess steam, ranges from 649 to $3,574 \mathrm{~kJ} / \mathrm{mol}$, for $\xi$ of 2.5 to 50, respectively. A $65 \%$ conversion extent is maintained in the electrolyzer. The calculated minimum energy requirement of a hydrolysis reactor when directly connected to the electrolyzer for several conversion extents in electrolyzer, ranges from 1727 to $17,136 \mathrm{~kJ} / \mathrm{mol}$, for electrolyzer conversion extents of 1 to 0.1 , respectively.

\subsection{Preferred operation of crystallization}

In Section 4.1, the energy requirement estimation is based on the assumption that the operation line of crystallization will obey the solubility curve.

It can be observed that the experimental operation line for the crystallization is below the solubility curve. This indicates more $\mathrm{CuCl}_{2}$ precipitated out of its aqueous solution in practical operations. The phenomenon does not mean the thermodynamic limit, i.e., solubility, was violated because when temperature decreases and $\mathrm{CuCl}_{2}$ crystallizes, some water will attach to the $\mathrm{CuCl}_{2}$ molecules in the form of hydrated water, as indicated in equation (7). The formation of hydrated water will reduce the amount of free water in the clear solution and further saturate the clear solution, consequently more $\mathrm{CuCl}_{2}$ will crystallize until a new equilibrium is reached. The phenomenon was also observed in the binary system of $\mathrm{CuCl}_{2}$ and water. Figure 9 illustrates the solubility curve and operation line of the crystallization in the binary system of $\mathrm{CuCl}_{2}$ and water. In the Figure, the solubility data was also collected from previous studies [31, 32], and the crystallization was started at $80^{\circ} \mathrm{C}$ and stopped at different lower temperatures. In the crystallization experiments (binary and ternary systems), a final temperature of approximately $20^{\circ} \mathrm{C}$ 
was examined to investigate using a fluid at ambient temperature, such as air or water, to remove heat from the crystallizer and avoid additional energy requirements. Also, the crystallization runtime (final temperature $\geq 20^{\circ} \mathrm{C}$ ) in Figures 4 and 9 was less than 120 minutes to ensure a manageable operating time in scaled up units.

In summary, the energy requirement estimation can be conservatively based on the assumption that the operation line of the crystallization of $\mathrm{CuCl}_{2}$ will obey the solubility curve for both the binary and ternary systems of $\mathrm{CuCl}_{2}$-water and $\mathrm{CuCl}_{2}$ - $\mathrm{HCl}$-water, respectively. The repetition may make the linkage of $\mathrm{CuCl}_{2}$ flows more compact and energy saving because it will reduce the size of the crystallization vessel and number of crystallization stages compared with otherwise the crystallization line is located above the solubility curve in Figures 4 and 9.

As discussed previously, the electrolyzer's outlet stream also includes $\mathrm{CuCl}$ if its conversion to $\mathrm{CuCl}_{2}$ is incomplete. As the formation of hydrated water caused by crystallization of $\mathrm{CuCl}_{2}$ will reduce the free water amount in the solution, it is expected that this concentrating effect may also facilitate the precipitation of $\mathrm{CuCl}$. Further investigations are needed to examine the operation line for the precipitation of $\mathrm{CuCl}$.

\section{CONCLUSIONS}

This paper performed a thermodynamic analysis on the electrolysis and hydrolysis reactions of the $\mathrm{Cu}-\mathrm{Cl}$ thermochemical hydrogen production cycle with an emphasis on linking the energy and mass flows. The following three integration methods were examined: directly introducing the aqueous outlet stream of the electrolyzer to the hydrolysis reactor, adopting an intermediate crystallizer to separate solid $\mathrm{CuCl}_{2}$ from the influent stream of the hydrolysis reactor, and vaporizing excess $\mathrm{H}_{2} \mathrm{O}$ before the hydrolysis reactor by using a spray dryer. Ongoing experiments are investigated the parameters of the electrolyzer operation.

Spray drying has the highest energy intensity of the three methods analyzed in this paper. Directly feeding the electrolyzer's outlet stream into the hydrolysis unit provides the most intensified integration design of the copper chloride flows. However, crystallization requires less energy input. High conversion of $\mathrm{CuCl}$ to $\mathrm{CuCl}_{2}$ in the electrolyzer is important, as well as low steam requirement in the hydrolysis reactor. A crystallizer can be a compact integration pathway to link the electrolyzer and 
hydrolysis reactor, by separating a portion of the $\mathrm{CuCl}_{2}$ and $\mathrm{CuCl}$ solids from the aqueous solution, as well as recycling the residual solution to the electrolyzer inlet. Electricity input to the $\mathrm{CuCl}$ electrolysis and heat input to the thermolysis will be investigated in future to evaluate clearly which options is most efficient to produce hydrogen.

\section{ACKNOWLEDGEMENTS}

The authors gratefully acknowledge the financial support of Ontario Research Excellence Fund (ORF) and Atomic Energy of Canada Limited (AECL).

\section{NOMENCLATURE}

$H \quad$ enthalpy, $\mathrm{kJ} / \mathrm{mol}$

$C_{p} \quad$ specific heat, $\mathrm{kJ} / \mathrm{mol} \cdot \mathrm{K}$

E energy, $\mathrm{kJ} / \mathrm{mol}$

$n, m \quad$ number of moles

Q thermal energy, $\mathrm{kJ} / \mathrm{mol}$

T Temperature, $\mathrm{K}$

\section{Greek Letters}

steam requirement (steam to copper (II) chloride ratio)

$\beta \quad$ enthalpy of vaporization, $\mathrm{kJ} / \mathrm{mol}$

\section{Subscripts}

total

w

water

$S$

solid

$r$

reaction

$i^{\circ} \mathrm{C} \quad$ output temperature of crystallizer

latent latent heat of vapourization

dehydration enthalpy of dehydration 


\section{REFERENCES}

[1] Berger E. BMW hydrogen near zero emission vehicle development. BMW CleanEnergy. CARB ZEV. Technology Symposium. 2006; 6- 13. September 2006.

[2] Herdem M.S. Combined coal gasification and alkaline water electrolyzer for hydrogen production. MASc Thesis, Department of Mechanical Engineering, University of Waterloo Canada. 2013.

[3] Abánades A. The challenge of hydrogen production for the transition to a CO2-free economy. Agronomy Research Biosystem Engineering Special Issue 1, 2012; 11-16.

[4] Tsutsumi A. Energy carriers and conversion systems with emphasis on hydrogen: thermodynamics of water splitting. Editor: Ohta T. ISBN: 978-1-84826-929-3. EOLSS Publishers Co Ltd. 2009, 1: 136-146.

[5] Sadhankar, R. R, Li. J, Li. H, Ryland, D, Suppiah, S. Hydrogen generation using high-temperature nuclear reactors. 55th Canadian Chemical Engineering Conference, Toronto, October, 2005.

[6] Lewis, M. A., Taylor, A. High Temperature Thermochemical Processes. DOE Hydrogen Program, Annual Progress Report, pp. 182 - 185, Washington DC, 2006.

[7] Kubo, S., Kasahara, S., Okuda, H., Terada, A., Tanaka, N., Inaba, Y., Ohashi. H., Inagaki, Y., Onuki, K., Hino, R. A pilot test plan of the thermochemical water-splitting iodine-sulfur process. Nucl Eng Des, 233, 355-362, 2004.

[8] Ghandehariun S., Wang Z, Rosen M. A., Naterer G. F. Reduction of hazards from copper (I) chloride in a Cu-Cl thermochemical hydrogen production plant. J Hazard Mater, 229 - 230, 48-56, 2012.

[9] Wang Z. L., Naterer G. F., Gabriel K. S., Gravelsins R, Daggupati V. N., Comparison of different copper-chlorine thermochemical cycles for hydrogen production. Int J Hydrogen Energ, 34, 3267-3276, 2009.

[10] Naterer G. F., Gabriel K., Wang Z., Daggupati V., Pope K., Marin G., Ghandehariun S., Xiong Y. Research progress of equipment and processes in the $\mathrm{Cu}-\mathrm{Cl}$ cycle. Progress Report in ORF Workshop. November 9, 2011, University of Ontario Institute of Technology, Oshawa, Canada. 2011. 
[11] Wang Z. L., Naterer G. F., Gabriel K. S., Gravelsins R., Daggupati V. N. New Cu-Cl thermochemical cycle for hydrogen production with reduced excess steam requirements. Int $\mathrm{J}$ Green Energy, 6, 616-626, 2009.

[12] Ferrandon M.S., Lewis M.A., Alvarez F., Shafirovich E. Hydrolysis of $\mathrm{CuCl}_{2}$ in the $\mathrm{Cu}-\mathrm{Cl}$ thermochemical cycle for hydrogen production: experimental studies using a spray reactor with an ultrasonic atomizer. Int J Hydrogen Energ, 35, 1895-1904, 2010.

[13] Lewis M. A., Ahmed S., Lvov S., Fan C. (2012) II.E.2 Membrane/Electrolyzer development in the Cu-Cl thermochemical cycle. DOE Hydrogen and Fuel Cells Program - FY 2012 Annual Progress Report.

[14] Aghahosseini S. System integration and optimization of copper-chlorine thermochemical cycles with various options for hydrogen production. PhD Thesis. Faculty of Engineering and Applied Science, University of Ontario Institute of Technology, August 2013.

[15] Pope K., Naterer G. F., Wang Z. L., Nitrogen carrier gas flow for reduced steam requirements of water splitting in a packed bed hydrolysis reactor. Exp Therm Fluid Sci, 44, 815-824, 2013.

[16] Xiao W. Z. Effect of source water blending on copper release in pipe distribution system: thermodynamic and empirical models. Ph D Thesis. University of Central Florida, Orlando, Florida. 2004; pp. 6-8 and 67-69.

[17] Basir A.S.M. Recovery of cupric chloride from spent copper etchant solutions: a mechanistic study. Hydrometallurgy, 69, 135-143, 2003.

[18] Richardson H. W. Handbook of copper compounds and applications. Published by CRC Press, ISBN 0824789989, 1997; pp. 64-92.

[19] Ulmanu C. Procedeu de obtinere directâ a clorurii copper (II)e anhidre. Romanian patent. Patent number 119755, issued date: September 30, 1987.

[20] Leray J. L. Growth kinetics of hydrated cupric chloride. J Cryst Growth, 3-4, 344-349, 1968.

[21] Wang Z., Xiong Y., Daggupati V. N., Secnik E., Naterer G. F. Non-equilibrium $\mathrm{CuCl}_{2}$ crystallization process in the $\mathrm{Cu}-\mathrm{Cl}$ hydrogen production cycle. International Conference on Hydrogen Production 2012. June 24-27, 2012, Seoul, Korea. Paper No. 447. 
[22] Ferrandon M. S., Lewis M. A., Tatterson D. F., Gross A., Doizi D., Croizé L., Dauvois V., Roujou J. L., Zanella Y., Carles P. Hydrogen production by the $\mathrm{Cu}-\mathrm{Cl}$ thermochemical cycle: Investigation of the key step of hydrolysing $\mathrm{CuCl}_{2}$ to $\mathrm{Cu}_{2} \mathrm{OCl}_{2}$ and $\mathrm{HCl}$ using a spray reactor. Int J Hydrogen Energ, 35, 992-1000, 2010.

[23] Lewis M. A., Masin J. G. The evaluation of alternative thermochemical cycles - Part II: the down selection process. Int J Hydrogen Energ, 34, 4125-4135, 2009.

[24] Daggupati V. N., Naterer G. F., Gabriel K. S., Gravelsins R. J., Wang Z. L. Equilibrium conversion in $\mathrm{Cu}-\mathrm{Cl}$ cycle multiphase processes of hydrogen production. Thermochim Acta, 496, 117-123, 2009.

[25] Crystallization experiments.

[26] Palmer S. L., Papangelakis V. G. Modelling cuprous chloride solubility in the CuCl-HCl- $\mathrm{H}_{2} \mathrm{O}$ ternary system from 298 K to 363 K. Proceedings: 2013 ORF Workshop on Clean Hydrogen Production with Water Splitting Technologies. Atomic Energy of Canada Limited - Chalk River Laboratories. April 22nd, 2013; pp. 122-129.

[27] van Kleef M. L., Daggupati V. N., Naterer G. F., Gabriel K. S., Secnik E, Wang Z. L. Crystallization kinetic study of cupric chloride recovery from electrolysis effluent solution for copper-chlorine thermochemical cycle for hydrogen production. Technical report for ORF project. Clean Energy Research Laboratory, August, 2011.

[28] Schmitt M., Janson O., Schmidt M., Hoffmann S., Schnelle W., Drechsler S. L., Rosner H. Crystalwater-induced switching of magnetically active orbitals in $\mathrm{CuCl}_{2}$. Phys Rev B, 79, 245119, 2009.

[29] Wang Z., Daggupati V. N., Marin G., Pope K., Xiong Y., Secnik E., Naterer G.F., Gabriel K.S. Towards integration of hydrolysis, decomposition and electrolysis processes of the $\mathrm{Cu}-\mathrm{Cl}$ thermochemical water splitting cycle. Int J Hydrogen Energ, 37: 16557-16569, 2012.

[30] Pope K., Naterer G. F. Wang Z. L. Effects of vapor pressure on thermodynamic equilibrium in multiphase flow for thermochemical hydrogen production. Heat Mass Transfer, 49, 1787-1794, 2013.

[31] Wang Z., Xiong Y., Daggupati V. N., Secnik E., Naterer G. F. Non-equilibrium $\mathrm{CuCl}_{2}$ 
crystallization process in the $\mathrm{Cu}-\mathrm{Cl}$ hydrogen production cycle. International Conference on Hydrogen Production 2012. June 24-27, 2012, Seoul, Korea.

[32] Poling B. E. 2007 Thomson GH, Friend DG, Rowley RL, Wilding W. Perry’s chemical engineers' handbook, section 2: physical and chemical data. McGraw-Hill Professional; 2007. ISBN-10/ ASIN: 0071511253, pp. 127.

\section{List of Captions:}

Table 1: Solubility of $\mathrm{CuCl}, \mathrm{CuCl}_{2}$ and $\mathrm{HCl}$

Table 2: Comparative energy requirement of three integration pathways

Figure 1: Direct feed of electrolyzer's outlet stream to hydrolysis unit

Figure 2: Spray dryer between electrolyzer's and hydrolysis reactor

Figure 3: Crystallizer between electrolyzer’s and hydrolysis reactor

Figure 4: Solubility and crystallization operation curves of the ternary system of $\mathrm{CuCl}_{2}, \mathrm{HCl}$, and water

Figure 5: Crystallization effectiveness for $1 \mathrm{~mol}$ of $\mathrm{CuCl}_{2}$ for an input of $2 \mathrm{~mol}$ of $\mathrm{CuCl}$ and $6 \mathrm{~mol}$ of $\mathrm{HCl}$, with a reaction extent of $65 \%$

Figure 6: Calculated energy inputs to the $\mathrm{CuCl}_{2}$ hydrolysis reactor

Figure 7: Thermal energy dissipated through crystallization

Figure 8: Excess water per mol of $\mathrm{CuCl}_{2}$ introduced to the hydrolysis reaction with reaction extent of the electrolyzer

Figure 9: Solubility and crystallization operation curves of the binary system of $\mathrm{CuCl}_{2}$ and water 
Table 1: Solubility of $\mathrm{CuCl}, \mathrm{CuCl}_{2}$ and $\mathrm{HCl}$

\begin{tabular}{|c|c|c|c|c|c|c|}
\hline \multirow{2}{*}{$\mathrm{T}\left[{ }^{\circ} \mathrm{C}\right]$} & \multicolumn{3}{|c|}{$\begin{array}{c}\text { Saturated solubility for 1 litre of solution } \\
\text { [mol] }\end{array}$} & \multicolumn{3}{|c|}{$\begin{array}{c}\text { Saturated solubility for 1 litre of solution } \\
\text { normalized to a constant quantity of } \mathrm{HCl} \text { [mol] }\end{array}$} \\
\cline { 2 - 7 } & $\mathrm{CuCl}$ & $\mathrm{CuCl}_{2}$ & $\mathrm{HCl}$ & $\mathrm{CuCl}$ & $\mathrm{CuCl}_{2}$ & $\mathrm{HCl}$ \\
\hline 20 & 1.46 & 2.31 & 8.66 & 1.03 & 1.63 & 6.09 \\
40 & 1.68 & 3.06 & 9.73 & 1.05 & 1.92 & 6.09 \\
60 & 2.08 & 3.26 & 8.55 & 1.48 & 2.32 & 6.09 \\
80 & 1.48 & 2.82 & 6.09 & 1.48 & 2.82 & 6.09 \\
\hline
\end{tabular}

Table 2: Comparative energy requirement of three integration pathways

\begin{tabular}{|c|c|c|c|c|}
\hline \multicolumn{2}{|c|}{$\begin{array}{l}\text { Hydrolysis and } \\
\text { crystalization with } 65 \% \\
\text { conversion extent in } \\
\text { electrolyzer }\end{array}$} & \multicolumn{2}{|c|}{$\begin{array}{l}\text { Hydrolysis reactor for } \\
\text { direct connection to } \\
\text { electrolyzer }\end{array}$} & $\begin{array}{l}\text { Hydrolysis and spray } \\
\text { drying }\end{array}$ \\
\hline $\begin{array}{l}\text { Excess } \\
\text { steam } \\
\text { required in } \\
\text { hydrolysis }\end{array}$ & $\begin{array}{l}\text { Energy } \\
\text { required } \\
{[\mathrm{kJ} / \mathrm{mol}]}\end{array}$ & $\begin{array}{l}\text { Conversion } \\
\text { extent in } \\
\text { electrolyzer }\end{array}$ & $\begin{array}{l}\text { Energy } \\
\text { required } \\
{[\mathrm{kJ} / \mathrm{mol}]}\end{array}$ & $\begin{array}{l}\text { Energy } \\
\text { required } \\
{[\mathrm{kJ} / \mathrm{mol}]}\end{array}$ \\
\hline 50 & 3574 & 0.1 & 17136 & \\
\hline 25 & 2034 & 0.25 & 6851 & \\
\hline 8 & 987 & 0.5 & 3432 & \\
\hline 2.5 & 649 & 0.65 & 2940 & \\
\hline & & 1 & 1727 & \\
\hline
\end{tabular}


Primary constituent: $\mathrm{Cu}_{2} \mathrm{OCl}_{2}$

Secondary constituents: $\mathrm{CuCl}_{2}, \mathrm{CuCl}$

Primary constituents: $\mathrm{H}_{2} \mathrm{O}, \mathrm{CuCl}, \mathrm{HCl}$

Secondary constituent: $\mathrm{CuCl}_{2}$

Electrolysis: $70-100^{\circ} \mathrm{C}$

$2 \mathrm{CuCl}(\mathrm{aq})+2 \mathrm{HCl}(\mathrm{aq}) \rightarrow$

$\mathrm{H}_{2}(\mathrm{~g})+2 \mathrm{CuCl}_{2}(\mathrm{aq})$

$\mathrm{H}_{2}$

Primary constituents:

$\mathrm{H}_{2} \mathrm{O}, \mathrm{CuCl}_{2}$

Secondary constituents:

$\mathrm{CuCl}, \mathrm{HCl}$
Hydrolysis: $360-390^{\circ} \mathrm{C}$

$\mathrm{CuCl}_{2}(\mathrm{aq}) \rightarrow \mathrm{H}_{2} \mathrm{O}(\mathrm{g})+\mathrm{CuCl}_{2}(\mathrm{~s})$

$\mathrm{CuCl}_{2}(\mathrm{~s})+\mathrm{H}_{2} \mathrm{O}(\mathrm{g}) \rightarrow$ $\mathrm{Cu}_{2} \mathrm{OCl}_{2}(\mathrm{~s})+2 \mathrm{HCl}(\mathrm{g})$

Primary constituent: $\mathrm{H}_{2} \mathrm{O}$

Secondary constituent: $\mathrm{HC}$
$\mathrm{HCl}, \mathrm{H}_{2} \mathrm{O}$

$\mathrm{HCl}-\mathrm{H}_{2} \mathrm{O}$ Separation

$\mathrm{H}_{2} \mathrm{O}$

Figure 1 


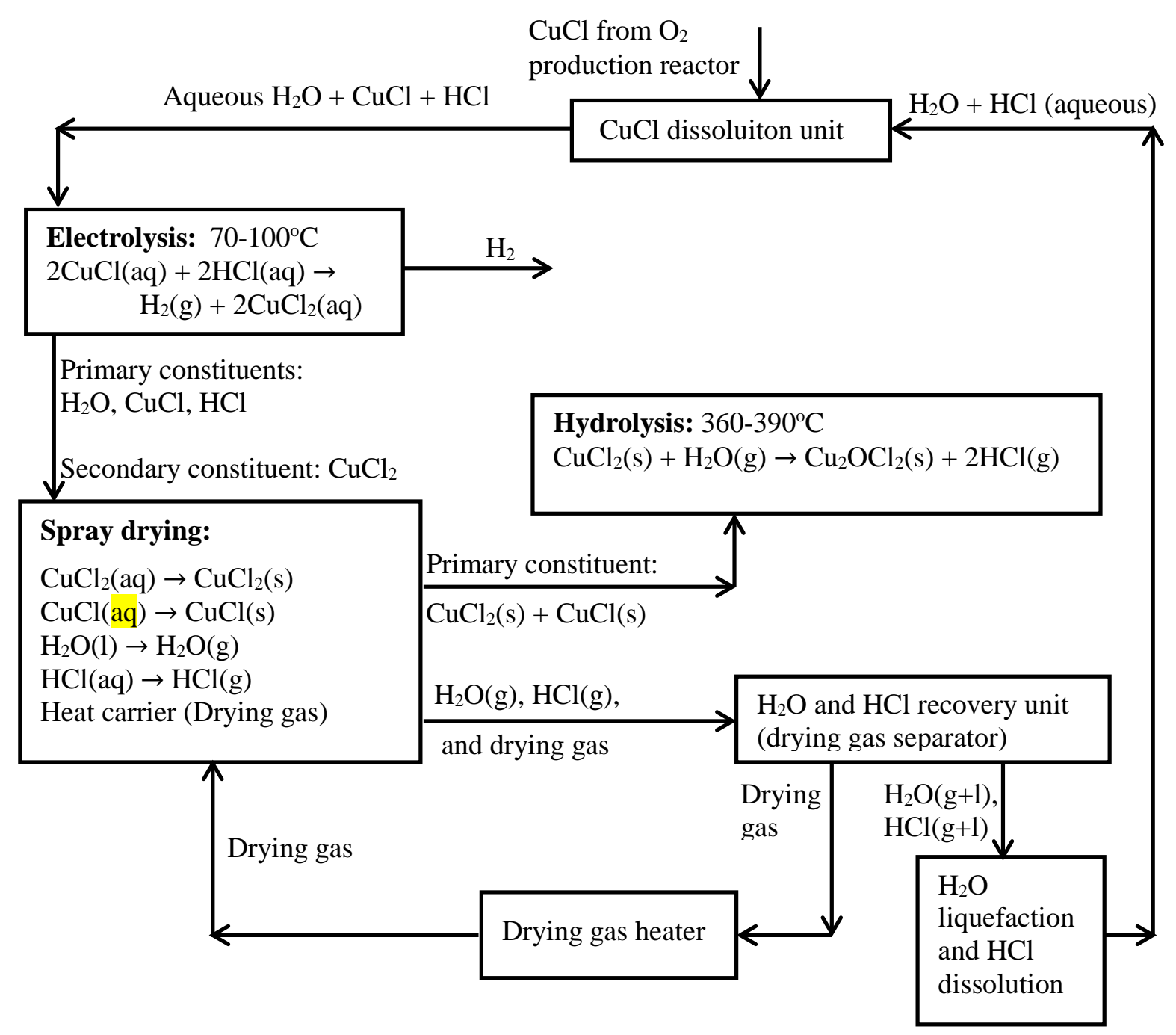

Figure 2

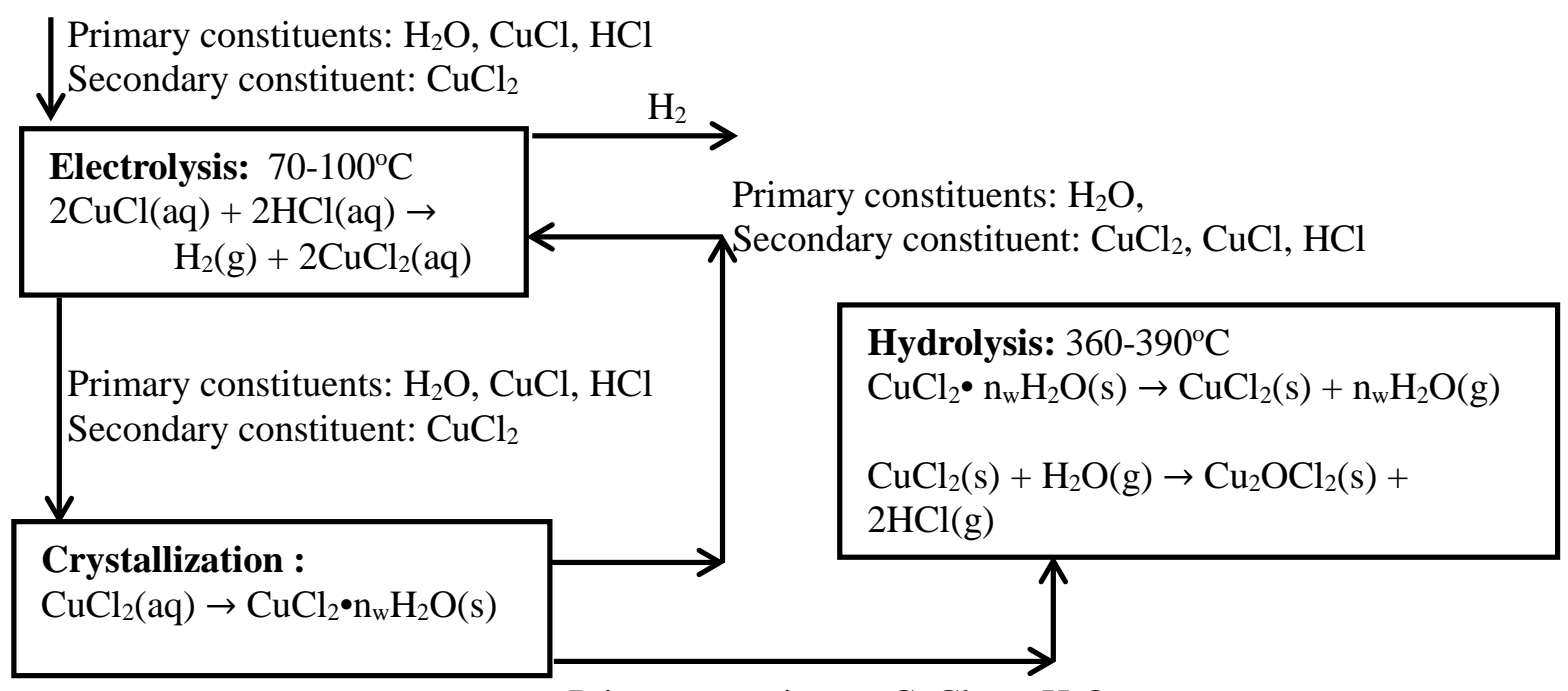

Primary constituent: $\mathrm{CuCl}_{2} \bullet \mathrm{n}_{\mathrm{w}} \mathrm{H}_{2} \mathrm{O}$

Secondary constituents: $\mathrm{H}_{2} \mathrm{O}, \mathrm{CuCl}$

Figure 3 


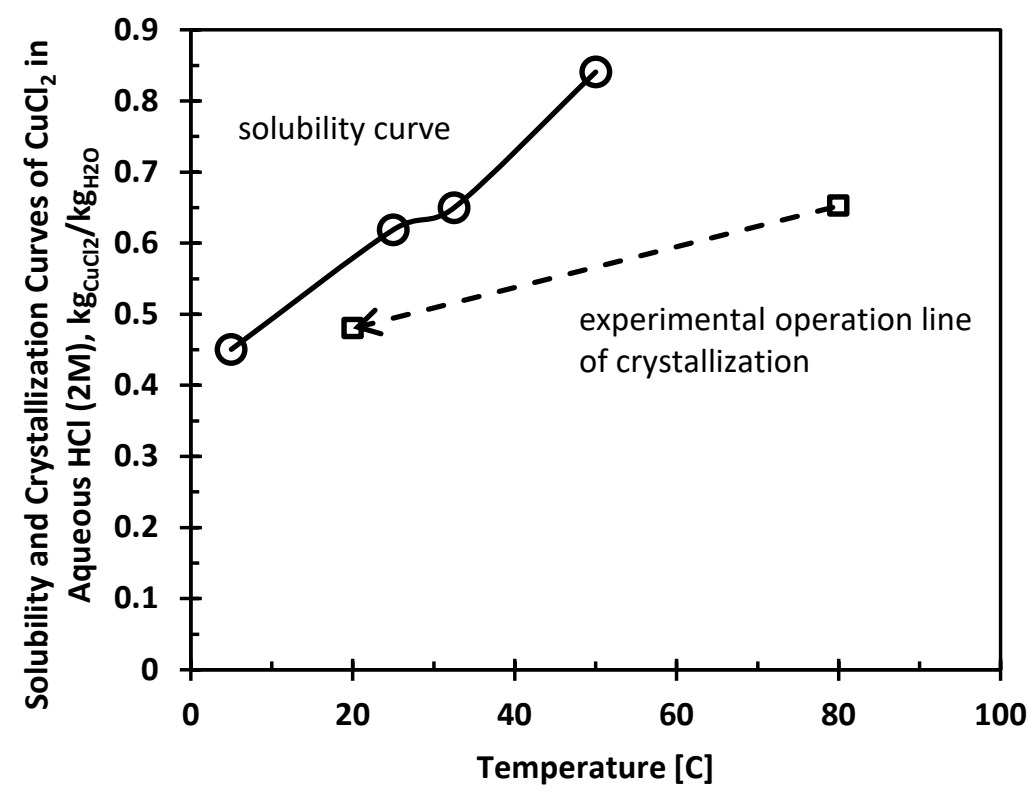

Figure 4

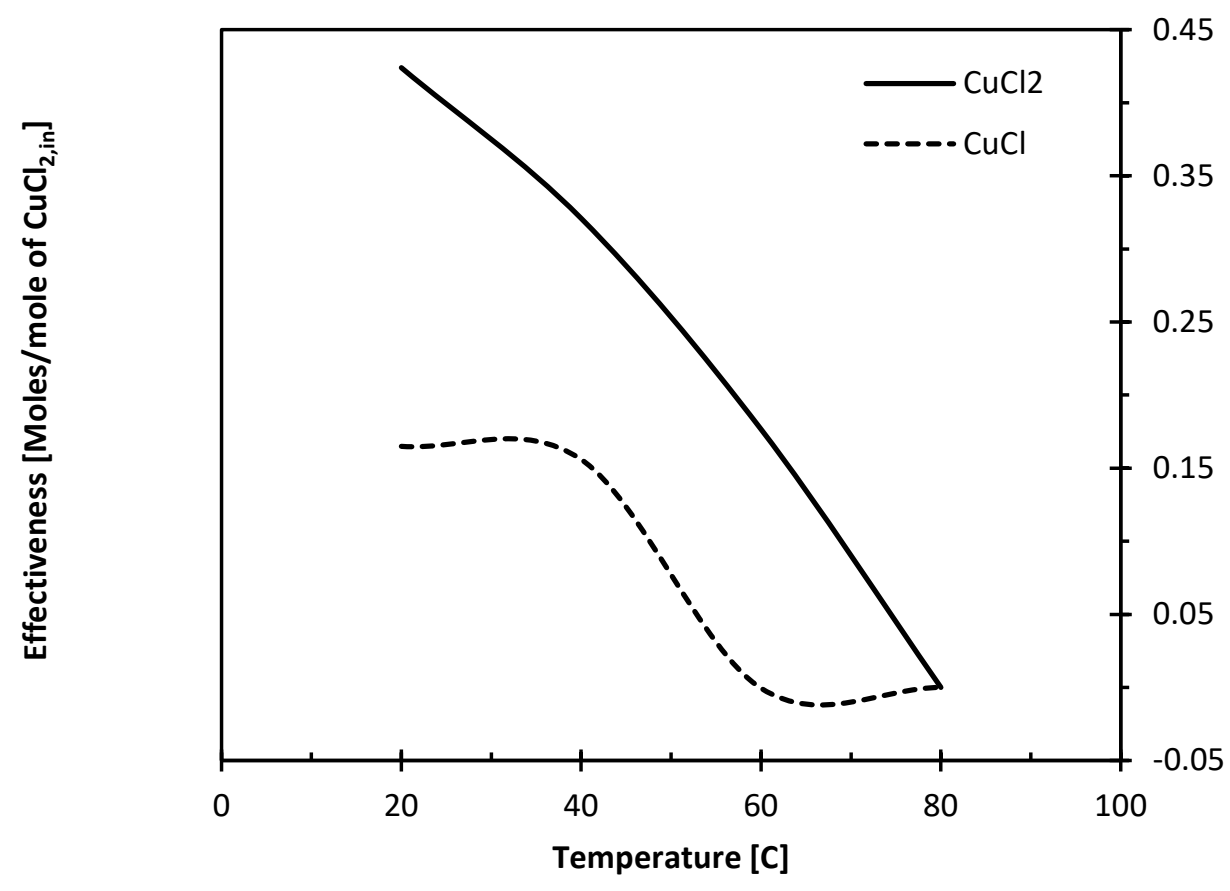

Figure 5 


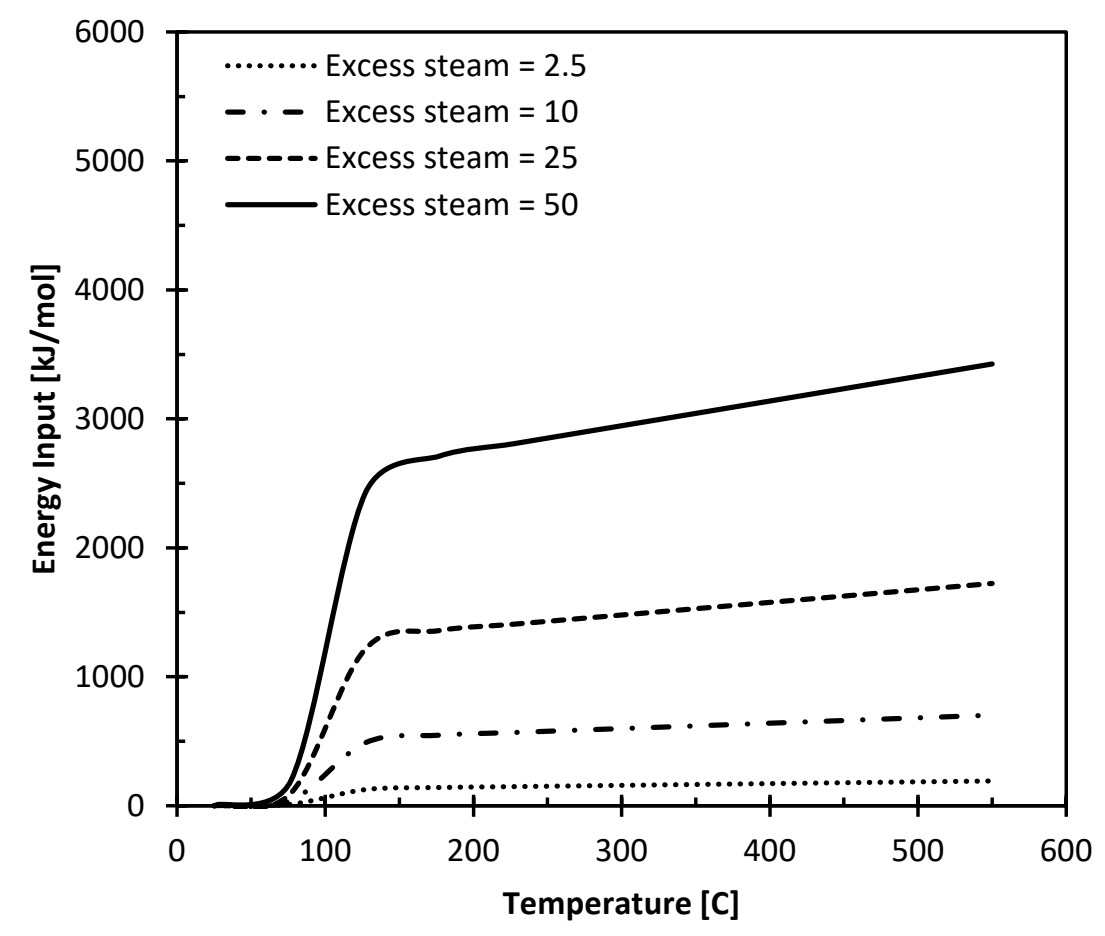

Figure 6

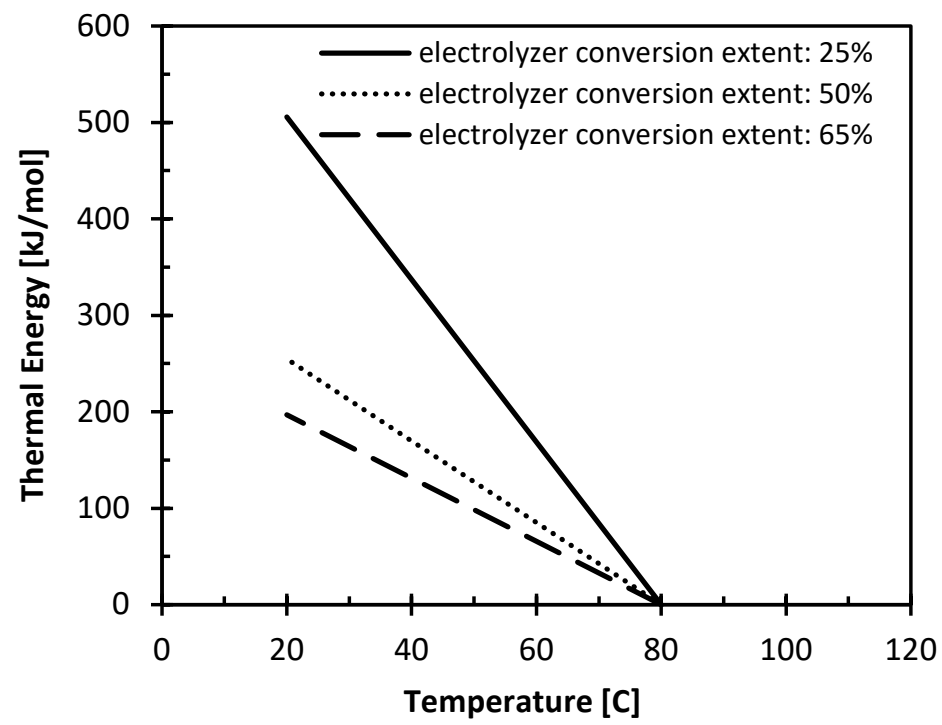

Figure 7 


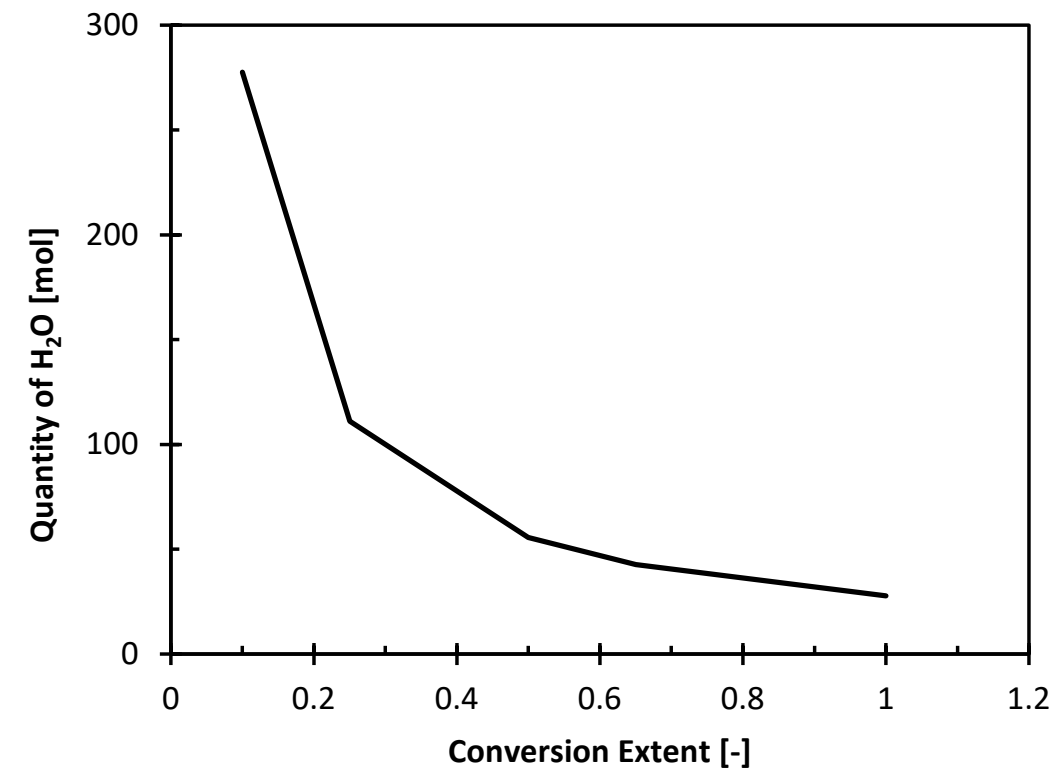

Figure 8

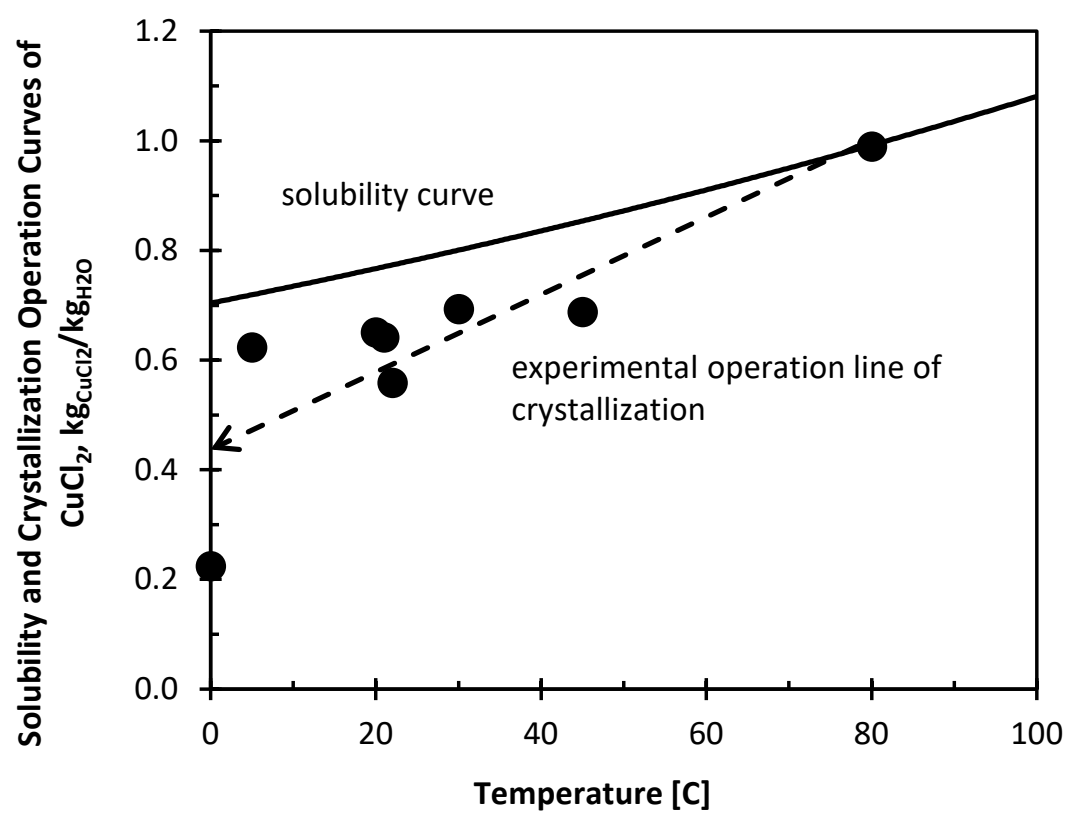

Figure 9 